\title{
INFLUENCE OF ORGANIC MANURES ON THE GROWTH OF DIABETES PREVENTIVE MEDICINAL PLANT GYNURA, Gynura procumbens
}

\author{
Akon, M. O. S., D. K. Datta, T. Biswas, K. Nakamura ${ }^{1}$ and M. K. Rahman \\ Department of Soil, Water and Environment, University of Dhaka, Dhaka 1000, Bangladesh; ${ }^{1}$ Institute \\ for Agro-Environmental Sciences, NARO, Kannondai 3-1-3, Tsukuba, Ibaraki 305-0035, Japan
}

\begin{abstract}
A pot experiment was carried out to evaluate the effects of various organic manures on the growth performance and biomass production of Gynura procumbens in the net house of the Department of Soil, Water and Environment, University of Dhaka. Seven types of manures, viz. ACI, BGF-1, Mazim, Vermicompost, Sufola, GTS and Poultry litter composts were used separately at the rate of $15 \mathrm{ton} / \mathrm{ha}$. Highest height $(78 \mathrm{~cm})$ in poultry litter compost, leaf number (208.33 no./plant) in sufola manure, leaf area $\left(53.64 \mathrm{~cm}^{2} / \mathrm{plant}\right) \mathrm{in}$ vermicompost, and branch (3.67 no./plant), girth $(3.07 \mathrm{~cm} / \mathrm{plant})$, fresh weight $(202.28 \mathrm{~g} / \mathrm{plant})$ and dry weight $(22.44 \mathrm{~g} / \mathrm{plant})$ were recorded in poultry litter compost treatment at harvest. Height, leaf area, and fresh and dry weights of leaf varied significantly $(\mathrm{p} \leq 0.5)$ and increased with time. Results showed that the overall best growth performance was achieved in poultry litter compost.
\end{abstract}

Key words: Growth, Gynura procumbens, biomass, poultry litter compost, organic manures.

\section{INTRODUCTION}

Organic manures have been shown to help preserve natural resources and reduce degradation of ecosystem (Mäder et al. 2002) and also improve the soil nutritional status as well as influence other soil properties. It also provides food for soil microorganisms. It increases the activity of microbes which in turn helps to convert unavailable plant nutrients into available form. Organic manures release nitrogen slowly, and leaching and volatilization losses are also very less as compared to inorganic fertilizers. The continuous chemical fertilizer use deteriorates crop while organic manures improve these properties (Watson et al. 2002). The increasing cost of chemical fertilizers and their harmful effects on the soil health are also an important consideration for the use of organic nutrients (Patel et al. 2005). Investigations show that vermicompost permanently enhances biological activity and can be used for the improvement of seed germination, flowering, growth and yield compared to commercial culture media which lack applicable nutrition (Atiyeh et al. 2000). The addition of poultry manure has been shown to improve the fertility of the cultivated soil by increasing the organic matter content, water holding capacity, oxygen diffusion rate and the aggregate stability of the soils (Mahimairaja et al. 1995).

Gynura procumbens sometimes called "longevity spinach" is an annual evergreen shrub and an edible vine found in Southeast Asia, especially in Malaysia, Thailand and Indonesia, which is of considerable medicinal value. Gynura procumbens is a species of Asteracea family, a small (1-3m high) plant. Traditionally, it is widely used in many different countries for the treatment of a wide variety of health ailments, such as kidney discomfort, rheumatism, diabetes mellitus, constipation, and hypertension (Tan et al. 2016). This plant is potential to produce secondary metabolites containing alkaloid, flavonoid, and coumarin. Kaempferol, quercetin, rutin and myricetin belonging to flavonoid have been isolated from $G$. procumbens leaves (Saiman et al. 2012). Flavonoid is potential, as an antioxidant, especially myricetin and kaempferol (Kaewseejan et al. 2015).

The economic and disease burden associated with non-communicable diseases especially diabetes put enormous pressure on fragile health systems in low-income countries. In the South Asian region, Bangladesh has the second largest number of adults with diabetes (5.1 million adults, 6.31\%) (Rahman et al. 2015). A little information is available in the literature on the cultivation of G. procumbens under Bangladesh edaphic conditions. Keeping this view in mind, the present experiment was conducted to 
evaluate the effects of eco-friendly organic manures ( 7 types) on growth performance and biomass production of $G$. procumbens- a diabetes preventive medicinal plant.

\section{MATERIAL AND METHODS}

\section{Soil sample collection and some physical and chemical properties}

Soil sample (0 to $15 \mathrm{~cm}$ depth) was collected from Ati, Keraniganj, Dhaka. The sample was airdried, ground and sieved through $3 \mathrm{~mm}$ sieve. The soil had a $\mathrm{pH}$ of $6.86\left(1: 2.5 \mathrm{w} / \mathrm{v}_{2} \mathrm{O}\right)$, organic carbon $0.26 \%$ (Wet oxidation method, Walkley and Black 1934), available nitrogen $24 \mathrm{mg} / \mathrm{kg}$ (Kjeldahl extraction, Marr and Cresser 1983), available phosphorus $6 \mathrm{mg} / \mathrm{kg}$ (Murphy and Riley 1962), sand $3.77 \%$, silt $68.23 \%$ and clay $28.00 \%$, textural class- silt loam (Bouyoucos 1962), and water holding capacity was $32 \%$.

\section{Pot experiment}

A pot experiment (Fig. 1) was carried out in the net house of the Department of Soil, Water and Environment, University of Dhaka. Six kilograms of soil were taken per earthen pot (height $22 \mathrm{~cm}$ and diameter $26 \mathrm{~cm})$. Seven types of organic manures manufactured by different companies were collected from the local market. The manures were ACI, BGF-1, Mazim, Vermicompost, Sufola, GTS and Poultry litter compost. The manures were properly mixed separately at the rate of 15 ton/ha with soil. Eight treatments with three replications were used. Three weeks old seedlings of $G$. procumbens were collected from Horticulture Center, Asadgate, Dhaka and one seedling was transplanted per pot. The pots were watered thrice a week in the morning. The height of the plant, the numbers of leaves and leaf area were measured at 15 days interval upto 120 days.

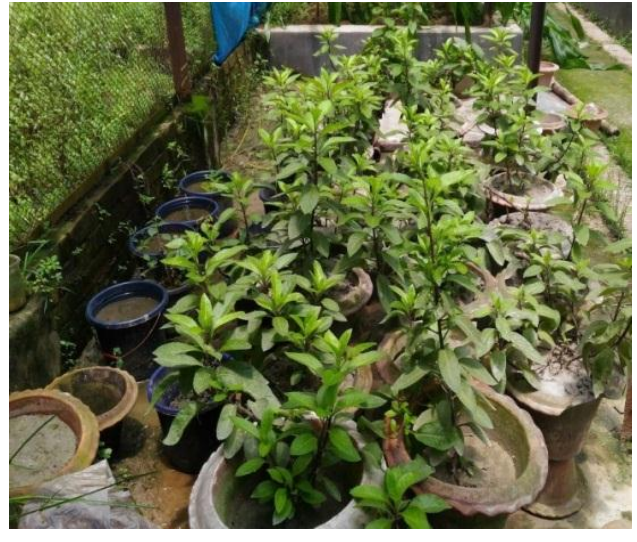

a

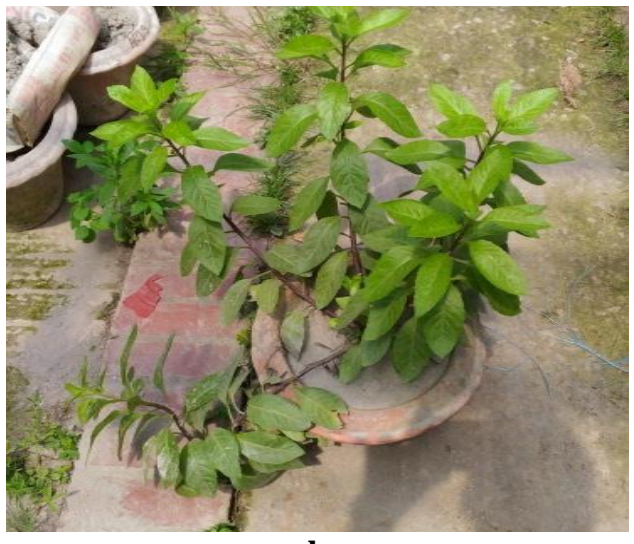

b

Fig. 1. Gynura procumbens plants: a. general view of the pot experiment; b. Gynura procumbens plant grown in poultry litter compost at harvest.

\section{Harvesting}

The plants were harvested as leaf, stem, root, washed with tap water and finally with distilled water, and wrapped with soft tissue paper. Immediately after the harvest, fresh weight of leaf, stem and root were taken and then air-dried in the room temperature and finally oven-dried at $65^{\circ} \mathrm{C}$ in the laboratory for two days. The dry weight of the samples was recorded and the samples were ground with a mechanical grinder and stored in the polythene bags for further chemical analysis. LSD test of the results was performed using Microsoft Excel 2013. 


\section{RESULTS AND DISCUSSION}

Plant growth was assessed in terms of plant height (Table 1), leaf number (Table 2), leaf area (Table 3 ), girth and branch number (Table 4), and biomass production as leaf, stem and root (Table 5). Height values of $15,30,45,60,75,90,105$ and 120 days increased significantly ( $\mathrm{p} \leq 0.5)$ (Table 1$)$. However, the highest height $(78 \mathrm{~cm})$ was observed in the poultry litter compost treatment after 120 days of growth. But a spectacular height was observed in vermicompost $(68 \mathrm{~cm})$ and ACI $(72.33 \mathrm{~cm})$ treatments.

Table 1. Effects of different organic manures on the height (cm) of Gynura procumbens.

\begin{tabular}{lcccccccc}
\hline $\begin{array}{l}\text { Treatments } \\
\text { (15 ton/ha) }\end{array}$ & \multicolumn{8}{c}{ Days after transplanting } \\
\cline { 2 - 9 } Control & 25.67 & 29.17 & 33.83 & 50.17 & 55.17 & 58.60 & 63.30 & 67.67 \\
ACI & 24.33 & 28.33 & 29.83 & 43.83 & 52.17 & 59.17 & 68.67 & 72.33 \\
BGF-1 & 18.67 & 22.67 & 23.50 & 31.50 & 39.17 & 42.30 & 50.17 & 52.33 \\
Mazim & 18.00 & 21.67 & 23.83 & 34.83 & 38.00 & 47.47 & 59.00 & 65.33 \\
Vermicompost & 23.67 & 30.00 & 31.50 & 39.33 & 50.00 & 57.67 & 63.17 & 68.00 \\
Sufola & 27.67 & 30.67 & 31.00 & 40.67 & 44.33 & 46.73 & 51.80 & 56.33 \\
GTS & 23.67 & 27.67 & 30.33 & 37.83 & 42.00 & 50.63 & 54.00 & 56.67 \\
Poultry litter & 27.67 & 30.67 & 32.50 & 42.17 & 57.33 & 68.60 & 74.00 & 78.00 \\
LSD at 5\% & 7.55 & 7.95 & 8.67 & 11.49 & 17.09 & 17.74 & 20.36 & 20.45 \\
\hline
\end{tabular}

The application of decomposed poultry manure, based on crop $\mathrm{N}$ requirements, was likely to provide more than other nutrients required by the crops (Edwards and Daniel 1992, Sims and Wolf 1994). The leaf number increased up to 120 days (Table 2). The highest values were recorded in treatment: Sufola. The leaf numbers at 30, 45, 60, 75, 90 and 105 days increased significantly $(\mathrm{p} \leq 0.5)$ (Table 2$)$. The minimum values of leaf number were observed in the control treatment.

Table 2. Effects of different organic manures on the leaf number per plant of Gynura procumbens.

\begin{tabular}{lcccccccc}
\hline Treatments & \multicolumn{8}{c}{ Days after transplanting } \\
\cline { 2 - 9 }$(\mathbf{1 5}$ ton/ha) & $\mathbf{1 5}$ & $\mathbf{3 0}$ & $\mathbf{4 5}$ & $\mathbf{6 0}$ & $\mathbf{7 5}$ & $\mathbf{9 0}$ & $\mathbf{1 0 5}$ & $\mathbf{1 2 0}$ \\
\hline Control & 28.33 & 44.00 & 65.00 & 79.33 & 81.33 & 86.00 & 102.33 & 131.67 \\
ACI & 23.33 & 33.67 & 75.67 & 102.33 & 104.33 & 101.33 & 121.67 & 180.33 \\
BGF-1 & 25.33 & 34.67 & 47.67 & 59.00 & 64.33 & 76.67 & 110.67 & 139.33 \\
Mazim & 21.33 & 27.33 & 40.33 & 50.33 & 48.67 & 88.33 & 105.33 & 146.67 \\
Vermicompost & 22.67 & 38.33 & 59.33 & 70.67 & 97.67 & 136.00 & 141.67 & 186.67 \\
Sufola & 21.33 & 29.00 & 41.33 & 49.67 & 85.67 & 119.67 & 155.33 & 208.33 \\
GTS & 26.00 & 42.00 & 64.00 & 74.33 & 86.00 & 110.33 & 136.00 & 162.33 \\
Poultry litter & 40.33 & 54.33 & 87.00 & 101.67 & 136.33 & 156.00 & 163.67 & 197.00 \\
LSD at 5\% & NS & 26.90 & 33.40 & 32.37 & 38.16 & 40.04 & 57.70 & NS \\
\hline
\end{tabular}

The results of the leaf area measurement are presented in Table 3. Leaf area was maximum (53.64 $\mathrm{cm}^{2} /$ plant) in vermicompost. The leaf area continuously increased up to 120 days of growth. The second highest value was obtained in poultry litter compost. Leaf area differs significantly due to organic manures.

The values of plant height (Table 1), leaf number (Table 2) and leaf area (Table 3) were recorded higher in the control treatment than in few other treatments, probably because of the uniform availability of nutrients in the composts used and collected from the local market, is not possible as the manufacturers do not maintain the standard grade for manufacturing organic manure. Brady and Weil (2002) concluded that the organic manures contain a passive fraction of 60 to 90 percent which is very slowly available to plants. Therefore, it might be possible that some of the manures contained comparatively larger portion of passive fraction and it took a long time to release nutrients and make 
them available to plants. Besides, various environmental factors, viz. temperature, light intensity, humidity, microbes and supply of nutrient elements also affect the rate of absorption and translocation of nutrients to influence the plant growth (Tisdale et al. 1995). The leaf area of some of the treatments was lower till 75 days probably because of slower rate of nutrient release from the organic manures and growth of some of the plants increased readily after 75 days as organic manures started to release nutrients onwards.

Table 3. Effects of different organic manures on the leaf area $\left(\mathrm{cm}^{2} / \mathrm{plant}\right)$ of Gynura procumbens.

\begin{tabular}{lcccccccc}
\hline Treatments & \multicolumn{7}{c}{ Days after transplanting } \\
\cline { 2 - 9 } (15 ton/ha) & $\mathbf{1 5}$ & $\mathbf{3 0}$ & $\mathbf{4 5}$ & $\mathbf{6 0}$ & $\mathbf{7 5}$ & $\mathbf{9 0}$ & $\mathbf{1 0 5}$ & $\mathbf{1 2 0}$ \\
\hline Control & 28.47 & 29.67 & 31.45 & 35.33 & 39.92 & 39.37 & 42.18 & 44.15 \\
ACI & 27.25 & 31.50 & 31.98 & 35.86 & 38.13 & 43.34 & 44.97 & 47.98 \\
BGF-1 & 18.83 & 22.31 & 26.49 & 32.81 & 36.24 & 39.35 & 42.19 & 46.20 \\
Mazim & 28.11 & 31.17 & 33.18 & 36.08 & 38.42 & 41.04 & 43.94 & 45.35 \\
Vermicompost & 27.42 & 31.91 & 34.28 & 40.25 & 44.62 & 47.18 & 50.22 & 53.64 \\
Sufola & 28.17 & 32.08 & 35.43 & 41.81 & 43.41 & 45.16 & 44.92 & 47.02 \\
GTS & 27.83 & 30.58 & 32.09 & 36.75 & 35.08 & 37.34 & 39.26 & 40.73 \\
Poultry litter & 19.33 & 22.75 & 23.67 & 27.25 & 32.63 & 38.49 & 45.28 & 48.10 \\
LSD at 5\% & NS & NS & 11.22 & 11.33 & 11.45 & NS & 10.65 & 11.16 \\
\hline
\end{tabular}

The results of the branch number per plant and the girth of the stem measured from $3 \mathrm{~cm}$ above the soil surface at 40 days interval are presented in Table 4. Branch number was the highest (3.67 no./plant) with the application of poultry litter. The minimum values for branch number per plant were obtained in the control. Branch number per plant varied significantly $(\mathrm{p} \leq 0.5)$ at 120 days, but did not vary significantly at 40 and 80 days (Table 4). The results of the girth value of the stem are presented in Table 4 . The girth value was maximum $(3.07 \mathrm{~cm})$ in poultry litter. The girth values varied significantly $(\mathrm{p} \leq 0.5)$ at 40 and 80 days, but did not vary significantly at 120 days. The minimum value $(2.77 \mathrm{~cm}) \mathrm{of}$ the girth of the stem was recorded in GTS.

Table 4. Effects of different organic manures on the number of branch per plant and girth (cm) of Gynura procumbens.

\begin{tabular}{lcccccc}
\hline $\begin{array}{l}\text { Treatments } \\
\text { (15 ton/ha) }\end{array}$ & \multicolumn{3}{c}{$\begin{array}{c}\text { Days after transplanting } \\
\text { (Branch/plant) }\end{array}$} & \multicolumn{3}{c}{$\begin{array}{c}\text { Days after transplanting } \\
\text { (Girth) }\end{array}$} \\
\cline { 2 - 7 } & $\mathbf{4 0}$ & $\mathbf{8 0}$ & $\mathbf{1 2 0}$ & $\mathbf{4 0}$ & $\mathbf{8 0}$ & $\mathbf{1 2 0}$ \\
\hline Control & 1.67 & 2.0 & 2.33 & 2.67 & 2.73 & 2.80 \\
ACI & 1.33 & 2.0 & 2.67 & 2.30 & 2.43 & 2.80 \\
BGF-1 & 1.33 & 1.67 & 2.33 & 2.43 & 2.50 & 2.83 \\
Mazim & 1.33 & 1.67 & 2.33 & 2.10 & 2.17 & 2.80 \\
Vermicompost & 1.67 & 2.0 & 3.0 & 2.10 & 2.27 & 2.97 \\
Sufola & 1.67 & 2.0 & 3.0 & 2.47 & 2.57 & 2.87 \\
GTS & 1.33 & 2.0 & 2.67 & 2.40 & 2.57 & 2.77 \\
Poultry litter & 1.67 & 2.67 & 3.67 & 2.40 & 2.63 & 3.07 \\
LSD at 5\% & NS & NS & 1.22 & 0.40 & 0.41 & NS \\
\hline
\end{tabular}

Fresh and dry matter yields

The yields of fresh and dry weights of leaf, stem and root are presented in Table 5. The highest yields were achieved due to application of poultry litter. The total fresh yields in the eight treatments including the control were 114.35, 130.26, 134.88, 136.47, 178.44, 174.96, 158.50 and $202.28 \mathrm{~g} / \mathrm{plant}$, respectively and the dry weight values in the similar treatments were $12.53,13.72,13.75,15.02,18.82$, 
17.81, 15.99 and $22.44 \mathrm{~g} / \mathrm{plant}$, respectively after harvest (Table 5). The maximum total yields of the fresh and dry weights were 202.28 and $22.44 \mathrm{~g} / \mathrm{plant}$, respectively in the poultry litter rich in nitrogen $(1.5 \%)$, phosphorus $(0.55 \%)$ and potassium $(0.95 \%)$. Nitrogen is the most imperative element for proper growth and development of plants which significantly increases the yield and its quality by playing vital role in biochemical and physiological functions of plant (Leghari et al. 2016).

Table 5. Effects of different organic manures on the fresh and dry weights of Gynura procumbens.

\begin{tabular}{lcccccccc}
\hline Treatments & \multicolumn{3}{l}{ Fresh weight (g/plant) } & \multicolumn{4}{c}{ Dry weight $(\mathrm{g} /$ plant $)$} \\
\cline { 2 - 9 } (15 ton/ha) & Leaf & Stem & Root & Total & Leaf & Stem & Root & Total \\
\hline Control & 70.79 & 38.86 & 4.70 & 114.35 & 5.17 & 5.65 & 1.71 & 12.53 \\
ACI & 74.65 & 51.52 & 4.09 & 130.26 & 5.23 & 7.22 & 1.26 & 13.72 \\
BGF-1 & 89.57 & 41.27 & 4.04 & 134.88 & 6.26 & 6.15 & 1.54 & 13.35 \\
Mazim & 91.73 & 40.34 & 4.40 & 136.47 & 6.80 & 6.59 & 1.63 & 15.02 \\
Vermicompost & 115.16 & 55.35 & 7.94 & 178.44 & 8.19 & 8.03 & 2.58 & 18.82 \\
Sufola & 114.74 & 54.43 & 5.79 & 174.96 & 8.10 & 7.89 & 1.82 & 17.81 \\
GTS & 106.37 & 45.93 & 6.20 & 158.50 & 7.29 & 6.64 & 2.06 & 15.99 \\
Poultry litter & 130.49 & 62.81 & 8.98 & 202.28 & 9.25 & 10.50 & 2.69 & 22.44 \\
LSD at 5\% & NS & NS & 4.93 & - & NS & 4.32 & 1.43 & - \\
\hline
\end{tabular}

The values for fresh weights of root varied significantly $(\mathrm{p} \leq 0.5)$, but the values for fresh weights of leaf and stem did not vary significantly. The values for dry weights of stem and root varied significantly $(\mathrm{p} \leq 0.5)$, but the values for dry weights of leaf did not vary significantly (Table 5). The results revealed that the most effective manure was poultry litter compost so far growth performance and biomass production of Gynura procumbens is concerned.

\section{REFERENCES}

Atiyeh, R. M., S. Subler, C. A. Edwards, G. Bachman, J. D. Metzger and W. Shuster. 2000. Effects of vermicomposts and composts on plant growth in horticulture container media and soil. Ped. Biol. 44: 579-590.

Bouyoucos, G. T. 1962. Hydrometer method improved for making particle size analysis of soils. Agron. J. 54: 461-465.

Brady, N. C. and R. R. Weil. 2002. The Nature and Properties of Soils. 13th ed. Pearson Education Pte. Ltd., Singapore. 960 pp.

Edwards, D. R. and T. C. Daniel. 1992. Environmental impacts of on-farm poultry waste disposal- a review. Bioresour. Technol. 41: 9-33.

Kaewseejan, N., V. Sutthikhum and S. Siriamornpun. 2015. Potential of Gynura procumbens leaves as source of flavonoid-enriched fraction with enhanced antioxidant capacity. J. Func. Food. 12(1): 120-128.

Leghari, S. J., N. A. Wahocho, G. M. Laghari, G. M. Bhabhan, K. H. Talpur, T. A. Bhutto, S. A. Wahocho and A. A. Lashari. 2016. Role of nitrogen for plant growth and development: a review. Adv. Environ. Biol. 10(9): 209-218.

Mader, P., A. Fliessbach, D. Dubois, L. Gunst, P. Fried and U. Niggli. 2002. Soil fertility and biodiversity in organic farming. Science. 296: 1694-1697.

Mahimairaja, S., N. S. Bolan and M. J. Hedley. 1995. Dissolution of phosphate rocks during the composting of poultry manure. Fertilizer Res. 40: 93-104. 
Marr, I. L. and M. S. Cresser. 1983. The lithosphere. In: Environmental Chemical Analysis. Blackie and Son, UK., pp. 155-182.

Murphy, J. and J. P. Riley. 1962. A modified single solution method for the determination of phosphate in natural waters. Anal. Chim. Acta. 27: 31-36

Patel, V. B., S. K. Singh, R. Asrey and Y. K. Sharma. 2005. Response of organic manures and biofertilizer on growth, fruit yield and quality of mango cv. Amrapali under high density orcharding. Karnataka J. Horti. 1(3): 51-56.

Rahman, M. S., S. Akter, S. K. Abe, M. R. Islam, M. N. I. Mondal, J. A. M. S. Rahman and M. M. Rahman. 2015. Awareness, treatment, and control of diabetes in Bangladesh: A nationwide population-based study. PLOS ONE. 10(2): 1-14.

Saiman, M. Z., N. R. Mustafa, A. E. Schulte, R. Ver-poorte and Y. H. Choi. 2012. Induction, characterization, and NMR-based metabolic profiling of advetitious root cultures from leaf explants of Gynura procumbens. Plant Cell, Tissue and Org. Cul. 109(3): 465-475.

Sims, J. T. and D. C. Wolf. 1994. Poultry waste management: agricultural and environmental issues. Advances Agron. 52: 1-83.

Tan, H. L., K. G. Chan, P. Pusparajah, L. H. Lee and B. H. Goh. 2016. Gynura procumbens: an overview of biological activities. Front. Pharmacol. 7: 52.

Tisdale, S. L., W. L. Nelson, J. D. Beaton and J. L. Havlin. 1995. Soil Fertility and Fertilizers. 5th ed. Prentice-Hall of India Private Ltd., New Delhi-110001. 634 pp.

Watson, C. A., D. Atkinson, P. Gosling, L. R. Jackson and F. W. Rayns. 2002. Managing soil fertility in organic farming systems. Soil Use Manage. 18: 239-247.

Walkley, A. and I. A. Black.1934. An examination of the Degtjareff method for determining soil organic matter and a proposed modification of the chromic acid titration method. Soil Sci. 37: 29-38. 